УДК 379.857

DOI 10.18101/2304-4446-2020-3-50-58

\title{
ОСОБЕННОСТИ ГОСУДАРСТВЕННОГО РЕГУЛИРОВАНИЯ СФЕРЫ ТУРИЗМА В РЕСПУБЛИКЕ БУРЯТИЯ
}

\section{(C) Старкова Ирина Ивановна}

кандидат социологических наук, доцент, Бурятский государственный университет имени Доржи Банзарова Россия, 670000, г. Улан-Удэ, ул. Смолина, 24а

E-mai: irina-ivanovna.8@mail.ru

\section{(C) Кондрашова Евгения Владимировна}

кандидат технических наук, доцент,

Восточно-Сибирский государственный институт культуры

Россия, 670031, г. Улан-Удэ, ул. Терешковой, 1

E-mail: con.evg@mail.ru

\section{(С) Фалилеева Оксана Юрьевна}

кандидат технических наук, доцент,

Восточно-Сибирский государственный институт культуры

Россия, 670031, г. Улан-Удэ, ул. Терешковой, 1

E-mail: faoxana@yandex.ru

Туризм на современном этапе - это одно из основных ведущих направлений экономики многих стран мира, поэтому роль государственных органов власти в туризме является достаточно важной. Она выражается в регулировании, поддержке и развитии данной отрасли. Однако для осуществления эффективной регуляторной политики необходимо соответствие законодательным актам установленных административных регламентов, то есть осуществление государственных функций органом исполнительной власти. В статье рассмотрены особенности государственного регулирования сферой туризма в Республике Бурятия, проведен анализ деятельности государственного регулирования сферы туризма в условиях пандемии, рассмотрены основные меры поддержки. Изучена нормативно-правовая база, регулирующая туристическую деятельность в Российской Федерации, а также в Республике Бурятия. В заключение авторы делают выводы, что успешное развитие туризма в республике зависит от восприятия этой отрасли на государственном уровне и государственной поддержки.

Ключевые слова: туризм; государственное регулирование; управление сферы туризма.

\section{Для цитирования}

Старкова И. И., Кондрашова Е. В., Фалилеева О. Ю. Особенности государственного регулирования сферы туризма в Республике Бурятия // Вестник Бурятского государственного университета. Экономика и менеджмент. 2020. № 3. С. 50-58.

В развитии туризма Республики Бурятия, как и в развитии любой другой отрасли, существуют различного рода проблемы. Среди них можно отметить недостаток туристической инфраструктуры, которая отвечала бы потребностям туристов на международном уровне (недостаток гостиниц туристического класса вместимостью более 100 мест и культурно-досуговых объектов, отсутствие вы- 
ставочных центров, СПА-комплексов, плохое состояние туристических объектов и объектов экскурсионного показа, несоответствие придорожного сервиса потребностям туристов). Медленная модернизация и создание инженерной инфраструктуры, что препятствует привлечению инвесторов. Высокие цены на транспорт и перевозку туристов, низкое качество обслуживания, недостаток продвижения Республики Бурятия как привлекательного туристического направления.

Также есть и специфические для сферы туризма Бурятии проблемы, стоящие перед министерством туризма: короткий туристический сезон, большая антропогенная нагрузка на природную среду, природоохранные запреты и ограничения на хозяйственную деятельность на Байкальской природной территории и, в частности, оборот земельных участков в границах объекта всемирного природного наследия ЮНЕСКО ${ }^{1}$.

Для решения некоторых проблем Министерство туризма Республики Бурятия разработало проект стратегии развития внутреннего и въездного туризма, в котором установило амбициозные цели и задачи - рост объема платных услуг туристам до 7,9 миллиарда рублей к 2035 г.

На сегодняшний день самой большой угрозой для туризма выступают ограничительные меры, вызванные сложной эпидемиологической ситуацией в стране вследствие распространения пандемии COVID-19.

Начиная с февраля 2020 г. распространившаяся коронавирусная инфекция спровоцировала резкое снижение туристического потока. В этой связи Правительство Российской Федерации признало туризм одной из сфер деятельности, где оказание первоочередной адресной поддержки - это одна из главных задач. По прогнозам экспертов, за 2020 г. в целом ожидается снижение объема платных услуг на 2,6 млрд рублей, что, в свою очередь, составляет порядка $80 \%$ от уровня 2019 г. $^{2}$

Итак, в первую очередь подробно рассмотрим состояние туристической отрасли в Республике Бурятия до карантинных мер. По данным на 1 января 2020 г., в сфере туризма в Бурятии работало:

- 507 коллективных средств размещения (организации по предоставлению туристам мест для ночевки);

- 27 туроператоров, свыше 100 турагентств;

- около 3600 работников отрасли.

За период 2019 г. в бюджет Республики Бурятия от субъектов сферы туризма поступило 163 млн рублей ${ }^{3}$.

В нашей работе мы провели анализ деятельности государственного регулирования сферы туризма в условиях пандемии, рассмотрели основные меры под-

\footnotetext{
${ }^{1}$ Материалы к заседанию круглого стола «О ходе реализации закона Республики Бурятия “О туризме”» Народный Хурал Республики Бурятия, Комитет по экономической политике, использованию природных ресурсов и охране окружающей среды. Улан-Удэ, 2018. 26 марта. $30 \mathrm{c}$.

Федеральное агентство по туризму: официальный сайт. URL: https://www.russiatourism.ru/news/16744/ (дата обращения: 11.07.2020).

3 Министерство туризма Республики Бурятия: официальный сайт. URL: https://egovburyatia.ru/minturizm/ (дата обращения: 11.07.2020).
} 
держки. Была изучена нормативно-правовая база, регулирующая туристическую деятельность в Российской Федерации, а также в Республике Бурятия.

В ходе исследования мы применили метод анализа нормативно-правовых источников на федеральном и региональном уровнях (табл. 1).

Законодательство в сфере туризма

Таблица 1

\begin{tabular}{|c|c|c|}
\hline № & $\begin{array}{c}\text { Нормативно-правовые документы, } \\
\text { регулирующие туристическую деятель- } \\
\text { ность на федеральном уровне }\end{array}$ & $\begin{array}{c}\text { Нормативно-правовые документы, } \\
\text { регулирующие туристическую } \\
\text { деятельность на региональном уровне }\end{array}$ \\
\hline 1 & $\begin{array}{l}\text { Федеральный закон от } 24 \text { ноября } 1996 \text { г. } \\
\text { N 132-Ф3 «Об основах туристской дея- } \\
\text { тельности в Российской Федерации». } \\
\text { Данный нормативно-правовой акт ре- } \\
\text { гламентирует все ситуации, которые мо- } \\
\text { гут произойти на этом рынке, устанавли- } \\
\text { вает права и обязанности сторон. Всего в } \\
\text { документе } 9 \text { глав (22 статьи) }\end{array}$ & $\begin{array}{l}\text { Закон Республики Бурятия от } 21 \text { ноября } \\
1995 \text { года N 210-І «О туризме», принят } \\
\text { Народным Хуралом Республики Буря- } \\
\text { тия } 21 \text { ноября } 1995 \text { г. Данный закон } \\
\text { регулирует отношения в сфере туризма } \\
\text { на территории Республики Бурятия }\end{array}$ \\
\hline 2 & $\begin{array}{l}\text { «Правила оказания услуг по реализации } \\
\text { туристского продукта», утверждены По- } \\
\text { становлением Правительства Российской } \\
\text { Федерации от } 18 \text { июля } 2007 \text { г. N } 452\end{array}$ & $\begin{array}{l}\text { Закон Республики Бурятия «О лечебно- } \\
\text { оздоровительных местностях, курортах } \\
\text { в Республике Бурятия» от } 16 \text { сентября } \\
1997 \text { г. № 559-І }\end{array}$ \\
\hline 3 & $\begin{array}{l}\text { «Правила страхования (стандартные) } \\
\text { гражданской ответственности за неис- } \\
\text { полнение или ненадлежащее исполне- } \\
\text { ние обязательств по договору о реализа- } \\
\text { ции туристского продукта». Утверждены } \\
\text { Всероссийским союзом страховщиков, } \\
\text { согласованы Федеральной службой стра- } \\
\text { хового надзора (письмо от } 16.04 .2007 \text { г. } \\
\text { №2210/0203) }\end{array}$ & $\begin{array}{l}\text { Закон Республики Бурятия «О зонах } \\
\text { экономического благоприятствования в } \\
\text { Республике Бурятия» от } 14 \text { марта } \\
2007 \text { г. № 2073-ІІІ }\end{array}$ \\
\hline 4 & 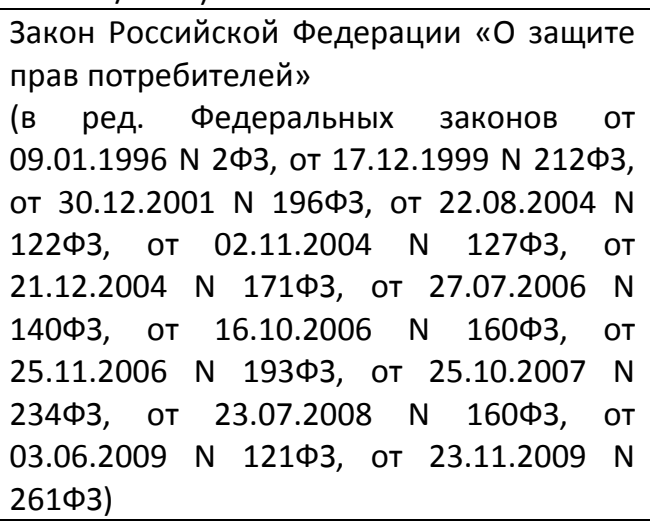 & \\
\hline
\end{tabular}

1 Федеральное агентство по туризму: официальный сайт. URL: https://www.russiatourism.ru/news/16744/ (дата обращения: 11.07.2020). 
И. И. Старкова, Е. В. Кондрашова, О. Ю. Фалилеева. Особенности государственного регулирования сферы туризма в Республике Бурятия

\begin{tabular}{|c|c|}
\hline 5 & $\begin{array}{l}\text { Письмо Роспотребнадзора от } 26 \text { августа } \\
2008 \text { г. № 01/9311832(д) «О принятии } \\
\text { мер по защите прав авиапассажиров, } \\
\text { пострадавших в результате задержек } \\
\text { авиарейсов» }\end{array}$ \\
\hline 6 & $\begin{array}{l}\text { «Общероссийский классификатор услуг } \\
\text { населению». Утвержден Постановлением } \\
\text { Госстандарта РФ от } 28 \text { июня } 1993 \text { г. N 163, } \\
\text { дата введения: 01.01.1994 }\end{array}$ \\
\hline 7 & $\begin{array}{l}\text { Федеральный Закон «О порядке выезда } \\
\text { из РФ и въезда в РФ» № 114-ФЗ от } \\
15.08 .96\end{array}$ \\
\hline 8 & $\begin{array}{l}\text { Постановление Правительства Россий- } \\
\text { ской Федерации от } 7 \text { мая } 2009 \text { г. N } 397 \\
\text { «О порядке пребывания на территории } \\
\text { РФ иностранных граждан и лиц без граж- } \\
\text { данства, прибывающих в РФ в туристиче- } \\
\text { ских целях на паромах, имеющих разре- } \\
\text { шения на пассажирские перевозки» }\end{array}$ \\
\hline 9 & $\begin{array}{l}\text { «Перечень портов, через которые допус- } \\
\text { кается въезд в Российскую Федерацию } \\
\text { иностранных граждан и лиц без граждан- } \\
\text { ства, прибывающих в Российскую Феде- } \\
\text { рацию в туристических целях на паромах, } \\
\text { имеющих разрешения на пассажирские } \\
\text { перевозки» } \\
\text { Утвержден Постановлением Правитель- } \\
\text { ства Российской Федерации от } 7 \text { мая } \\
2009 \text { г. N } 397\end{array}$ \\
\hline 10 & $\begin{array}{l}\text { «Об утверждении положения о пребыва- } \\
\text { нии на территории Российской Федера- } \\
\text { ции иностранных граждан пассажиров } \\
\text { круизных судов» } \\
\text { Постановление Правительства Россий- } \\
\text { ской Федерации от } 28 \text { августа } 2003 \text { г. } \\
\text { N } 532\end{array}$ \\
\hline 11 & $\begin{array}{l}\text { «Об утверждении положения об уста- } \\
\text { новлении формы визы, порядка и усло- } \\
\text { вий ее оформления и выдачи, продления } \\
\text { срока ее действия, } \\
\text { восстановления ее в случае утраты, а } \\
\text { также порядка аннулирования визы» } \\
\text { Постановление Правительства Россий- } \\
\text { ской Федерации от } 9 \text { июня } 2003 \text { г. N } 335 \\
\text { (в ред. Постановлений Правительства РФ } \\
\text { от 04.10.2007 N 635, от } 24.12 .2008 \text { N } 1021 \text {, } \\
\text { от 08.05.2009 N 398) }\end{array}$ \\
\hline
\end{tabular}


12 «Об утверждении положения о предоставлении помощи в возвращении в Российскую Федерацию гражданам Российской Федерации, оказавшимся на территории иностранного государства без средств к существованию»

Постановление Правительства Российской Федерации от 31 мая 2010 г. № 370

В свете событий, происходящих на фоне распространения новой короновирусной инфекции не только в нашем регионе, но и во всем мире, принимаются новые дополнительные меры по поддержке множества сфер жизнедеятельности. К данным мерам в первую очередь относятся меры поддержки сферы туризма.

В нашей работе мы провели анализ деятельности государственного регулирования сферы туризма в условиях пандемии, рассмотрели основные меры поддержки. Изучены принимаемые меры поддержки на федеральном и региональном уровнях в условиях распространения новой коронавирусной инфекции (табл. 2).

Таблица 2

Меры поддержки туристической отрасли

\begin{tabular}{|c|c|c|}
\hline № & $\begin{array}{c}\text { Меры поддержки, принимаемые } \\
\text { на федеральном уровне, в условиях } \\
\text { распространения новой } \\
\text { коронавирусной инфекции }\end{array}$ & $\begin{array}{c}\text { Меры поддержки, принимаемые } \\
\text { на региональном уровне, в условиях } \\
\text { распространения новой } \\
\text { коронавирусной инфекции }\end{array}$ \\
\hline 1 & $\begin{array}{l}\text { Распоряжение от } 7 \text { апреля } 2020 \text { г. № } \\
\text { 909-р. О субсидиях для туроператоров } \\
\text { на возмещение убытков, связанных с } \\
\text { авиаперевозками }\end{array}$ & $\begin{array}{l}\text { Субсидии на финансовое обеспечение } \\
\text { затрат по аренде нежилых помещений } \\
\text { (офисов). В размере } 80 \% \text { затрат, но не } \\
\text { более } 400 \text { р. за } 1 \text { м }^{2} \text { для туроператоров } \\
\text { республики. } \\
\text { Затраты за период с } 1 \text { апреля } 2020 \text { г. по } \\
30 \text { июня } 2020 \text { г. по аренде помещений } \\
\text { на территории Республики Бурятия, ис- } \\
\text { пользуемых для оказания услуг по реа- } \\
\text { лизации туристического продукта }\end{array}$ \\
\hline 2 & $\begin{array}{l}\text { Распоряжение Правительства Россий- } \\
\text { ской Федерации от 04.04.2020 № 898-р. } \\
\text { Доступ к фонду персональной ответ- } \\
\text { ственности туроператора (ФПО) (воз- } \\
\text { можность использовать накопленные } \\
\text { средства ФПО для возврата денежных } \\
\text { средств туристам) }\end{array}$ & $\begin{array}{l}\text { Субсидии на возмещение затрат по } \\
\text { оплате коммунальных услуг. } \\
\text { В размере } 80 \% \text { затрат за период с } 1 \text { мар- } \\
\text { та } 2020 \text { г. по } 31 \text { мая } 2020 \text { г. } \\
\text { Право на получение субсидий имеют Юл } \\
\text { (ИП), предоставляющие круглогодично } \\
\text { услуги коллективных средств размеще- } \\
\text { ния. } \\
\text { В перечень коммунальных услуг, оплата } \\
\text { за потребление которых возмещается из } \\
\text { средств республиканского бюджета, } \\
\text { входят электроснабжение, отопление }\end{array}$ \\
\hline
\end{tabular}


И. И. Старкова, Е. В. Кондрашова, О. Ю. Фалилеева. Особенности государственного регулирования сферы туризма в Республике Бурятия

\begin{tabular}{|c|c|c|}
\hline & & $\begin{array}{l}\text { (твердое топливо), горячее водоснабже- } \\
\text { ние, холодное водоснабжение, водоот- } \\
\text { ведение (вывоз ЖБО) }\end{array}$ \\
\hline 3 & $\begin{array}{l}\text { Распоряжение от } 18 \text { марта } 2020 \text { г. } \\
\text { №660-р о взносах туроператоров в } \\
\text { сфере выездного туризма в резервный } \\
\text { фонд Ассоциации «Турпомощь» на } \\
2020 \text { год. Размер взноса зарегистриро- } \\
\text { ванных туроператоров составит } 1 \\
\text { рубль }\end{array}$ & $\begin{array}{l}\text { Гранты в форме субсидий в целях под- } \\
\text { держки проектов развития сельского, } \\
\text { экологического, социального туризма и } \\
\text { проектов, направленных на продвиже- } \\
\text { ние туристического потенциала и повы- } \\
\text { шение туристической привлекательности } \\
\text { Республики Бурятия. } \\
\text { Прием заявок идет с } 27 \text { апреля по } 16 \\
\text { мая. Общий объем средств на предо- } \\
\text { ставление грантов составляет } 5 \text { млн р. } \\
\text { На один грант не более } 250 \text { тыс. рублей, } \\
\text { по экологическому туризму не более } 1 \\
\text { ООО тыс. р. }\end{array}$ \\
\hline 4 & $\begin{array}{l}\text { Отсрочка предоставления бухгалтер- } \\
\text { ской и отраслевой отчетности, а также } \\
\text { порядок подачи сведений, подтвер- } \\
\text { ждающих обеспечение ответственно- } \\
\text { сти туроператора. Перенос на } 12 \text { мая } \\
2020 \text { г. }\end{array}$ & $\begin{array}{l}\text { Возмещение части затрат за счет средств } \\
\text { республиканского бюджета субъектам } \\
\text { малого и среднего предпринимательства } \\
\text { в сфере туризма субсидий по } 11 \text { направ- } \\
\text { лениям, установленным постановлением } \\
\text { Правительства Республики Бурятия от } \\
07.12 .2009 \text { № } 453\end{array}$ \\
\hline 5 & $\begin{array}{l}\text { Возмещение расходов авиакомпаний } \\
\text { на вывоз туристов. Утверждены прави- } \\
\text { ла предоставления субсидий } \\
\text { организациям воздушного транспорта } \\
\text { на возмещение затрат при вывозе } \\
\text { граждан из иностранных государств }\end{array}$ & $\begin{array}{l}\text { В настоящее время вносятся дополни- } \\
\text { тельные направления субсидирования: } \\
\text { - возмещение части затрат, связанных с } \\
\text { финансовым обеспечением ответствен- } \\
\text { ности туроператора (договор или дого- } \\
\text { воры страхования гражданской ответ- } \\
\text { ственности за неисполнение обяза- } \\
\text { тельств по договору о реализации ту- } \\
\text { ристского продукта); } \\
\text { - возмещение части затрат, связанных со } \\
\text { строительством и/или оборудованием } \\
\text { пеллетных котельных в коллективных } \\
\text { средствах размещения, а также расходов } \\
\text { на проведение экологической эксперти- } \\
\text { зы; } \\
\text { - возмещение части затрат, связанных с } \\
\text { приобретением новых снегоходов, мото- } \\
\text { техники (включая мотовездеходы), тех- } \\
\text { ники зимней эксплуатации, таких как } \\
\text { суда на воздушной подушке, вездеходы } \\
\text { на шинах низкого давления }\end{array}$ \\
\hline 6 & $\begin{array}{l}\text { Возврат средств при отмене и перено- } \\
\text { се мероприятий. Утверждено положе- } \\
\text { ние об особенностях отмены, замены } \\
\text { или переноса проводимого организа- }\end{array}$ & \\
\hline
\end{tabular}




\begin{tabular}{|c|c|}
\hline & $\begin{array}{l}\text { цией исполнительских искусств или } \\
\text { музеем зрелищного мероприятия }\end{array}$ \\
\hline 7 & $\begin{array}{l}\text { Финансовая помощь гражданам РФ, } \\
\text { оказавшимся за рубежом. Помощь } \\
\text { будет оказана гражданам РФ, } \\
\text { находящимся за рубежом, имеющим } \\
\text { проездные документы для возвраще- } \\
\text { ния в РФ в период с } 16 \text { марта по } 31 \text { мая } \\
2020 \text { г. }\end{array}$ \\
\hline 8 & $\begin{array}{l}\text { Беспроцентные кредиты на выплату } \\
\text { зарплат. Кредитование предприятий из } \\
\text { пострадавших отраслей на выплату } \\
\text { зарплат сотрудникам будут осуществ- } \\
\text { лять банки при поддержке Централь- } \\
\text { ного банка. Гарантия по кредиту обес- } \\
\text { печивается поручительством ВЭЮ } \\
\text { (75\%). Кредит будет предоставляться } \\
\text { по ставке 0\% первые } 6 \text { месяцев и 4\% - } \\
\text { в последующие } 6 \text { месяцев }\end{array}$ \\
\hline 9 & $\begin{array}{l}\text { Мораторий на банкротство (постра- } \\
\text { давшие отрасли). Мораторий сроком } 6 \\
\text { месяцев будет дан организациям с } \\
\text { принадлежностью (по основному виду } \\
\text { деятельности) к одной из отраслей, } \\
\text { признанной пострадавшей от панде- } \\
\text { мии, в т. ч. ОКВЭД 55, } 56 \text { и } 79\end{array}$ \\
\hline 10 & $\begin{array}{l}\text { Мораторий на налоговые санкции. За- } \\
\text { прет на санкции за несвоевременную } \\
\text { подачу документов. Предоставление } \\
\text { налоговых деклараций - сроки про- } \\
\text { длены на } 3 \text { месяца. На } 1 \text { июня } 2020 \text { г. } \\
\text { перенесены сроки начала проведения } \\
\text { налоговых проверок }\end{array}$ \\
\hline 11 & $\begin{array}{l}\text { Субсидии на возобновление деятель- } \\
\text { ности. Кредитование предприятий из } \\
\text { пострадавших отраслей на расходы по } \\
\text { выплате заработной платы сотрудни- } \\
\text { кам и по погашению кредитов, ранее } \\
\text { полученных по договорам, заключен- } \\
\text { ным в рамках Правил предоставления } \\
\text { субсидий по льготной ставке, либо в } \\
\text { рамках Правил предоставления субси- } \\
\text { дий для поддержки и сохранения за- } \\
\text { нятости. Кредит становится субсидией } \\
\text { при соответствии заданным условиям }\end{array}$ \\
\hline 12 & $\begin{array}{l}\text { Снижение страховых взносов. Для ор- } \\
\text { ганизаций и ИП, включенных в Единый } \\
\text { реестр МСП, совокупный объем стра- }\end{array}$ \\
\hline
\end{tabular}


И. И. Старкова, Е. В. Кондрашова, О. Ю. Фалилеева. Особенности государственного регулирования сферы туризма в Республике Бурятия

ховых взносов снижается с 30 до 15\%

для части зарплат, превышающей

МРОТ (12130 р.). Ставка взносов в ПФР

составит $10 \%$, в ФОМС - 5\%. Взносы в

ФСС (по нетрудоспособности и мате-

ринству) не уплачиваются

Принятые меры, по мнению многих экспертов, пока не показывают однозначных результатов. В этой связи экспертами разрабатывается программа по предельно быстрому посткризисному восстановлению отрасли. Программа направлена на восстановление туристической сферы после нормализации ситуации, также обсуждаются вопросы стимулирования внутреннего и въездного туризма. Важнейшими задачами при этом остаются защита конечного потребителя и соблюдение интересов турбизнеса в соответствии с нормами действующего законодательства.

На данный момент в Бурятии активно идет прием чартеров «TUI Россия» из Москвы. Туроператор уже сотрудничал с регионом, организовывал рекламные туры, а пандемия и закрытие границ только подтолкнули его к более масштабному проекту. Местный рынок, в свою очередь, консолидировался, чтобы показать туристам не только Байкал, но и бурятскую экзотику в целом. Переориентация крупных туроператоров на внутренний и въездной туризм, связанная с пандемией, безусловно, повлияла на запуск рейса. В данный момент правительство обратило внимание на регион и готово поддерживать развитие внутреннего туризма, в этой связи главной задачей перед туроператорами стоит разработка заманчивых программ.

\section{Литература}

1. Захарова Е. П. Туристская деятельность в Российской Федерации: источники правового регулирования // Вестник Саратовской государственной юридической академии. 2013. № 6. С. 87-91.

2. Правовое обеспечение туризма: учебник / под ред. Е. Л. Писаревского. М.: Федеральное агентство по туризму, 2014. 336 с.

\section{CONSIDERATIONS FOR GOVERNMENT REGULATION OF TOURISM IN THE REPUBLIC OF BURYATIA}

Irina I. Starkova

Cand. Sci. (Sociol.), A/Prof.,

Dorzhi Banzarov Buryat State University

24a Smolina St., Ulan-Ude 670000, Russia

E-mail: irina-ivanovna.8@mail.ru

Evgeniya V. Kondrashova

Cand. Sci. (Engineering), A/Prof.,

East-Siberian State Institute of Culture

1 Tereshkovoy St., Ulan-Ude 670031, Russia

E-mail: con.evg@mail.ru 
Oksana Yu. Falileeva

Cand. Sci. (Engineering), A/Prof.,

East-Siberian State Institute of Culture

1 Tereshkovoy St., Ulan-Ude 670031, Russia

E-mail: faoxana@yandex.ru

Nowadays, tourism is one of the major directions of the economy of many world countries; therefore, the role of state authorities in tourism is quite important. It is expressed in the regulation, support and development of this sector. However, the effective regulatory policy is possible only in compliance with legal acts and administrative provisions that is when the executive branch exercise the state functions. The article analyzes the features of tourism state regulation in the Republic of Buryatia, the state activity in tourism sector in the conditions of a pandemic, the main support measures. We have studied legal and regulatory setting governing tourist activities in the Russian Federation, as well as in the Republic of Buryatia. It is concluded that the successful development of tourism in the republic depends on the state support of this sector.

Keywords: tourism; government regulations; tourism management. 